Удк: 616.89-008.19-02:616-001.45]:355.123

\title{
HOW THE MULTIFUNCTIONAL NANOCARRIER MAKES THE MEDICINE «SMART»?
}

\author{
Rostyslav Stoika \\ Institute of Cell Biology, NAS of Ukraine, Lviv, Ukraine, stoika@cellbiol.Iviv.ua
}

Key words: pharmacology, molecular medicine, nanotechnology, cancerogenesis, drug-resistance

\begin{abstract}
Two principal problems that exist in pharmaceutics are the non-addressed action of medicines causing negative side effects in the organism and rapid development of drug resistance in treated patients. Here we present examples how drug encapsulation in the polymeric or mineral nanoscale platform can enhance its treatment effect, improve its targeting in the organism, as well as provide the drug with ability to circumvent drug-resistance mechanisms. Thus, such encapsulation makes the drug "smarter" during its action.
\end{abstract}

\section{ЯК МУЛЬТИФУНКЦІОНАЛЬНИЙ НАНОНОСІЙ РОБИТЬ МЕДИЦИНУ «РОЗУМНОю»?}

\author{
Ростислав Стойка \\ Інститут біології клітини Національної академії наук України, Львів, Україна, \\ stoika@cellbiol.Iviv.ua
}

Ключові слова: фармакологія, молекулярна медицина, нанотехнології, онкогенез, медикаментозна резистентність

Дві основні проблеми, що існують у фармації - це невідповідна дія лікарських засобів, що спричиняють негативні побічні ефекти в організмі та швидкий розвиток резистентності ліків під час лікування пацієнтів. У цьому огляді літератури наводимо приклади того, як інкапсуляція лікарського засобу на полімерній або мінеральній наномасштабній платформі може посилити ефект лікування, покращити його орієнтацію в організмі, а також забезпечити препарат новою здатністю оминати механізми резистентності до лікарських засобів. Таким чином, така інкапсуляція робить препарат «розумнішим» під час його дії.

Classical medicines consist of the drug substance together with inert (non-toxic, mostly useless) filling substance that is utilized because the drug is often applied in mini (micro) amount. While medicines of new generation consist of drug immobilized on the delivery nanoscale platform (polymeric micelle, hydrogel, or nanoparticle, used as carrier). This platform should be "smart" in order to overcome two major problems in pharmaceutics: 1) low efficiency of drugs due to their non-addressed action (only $0.01 \%$ of drugs applied intravenously can reach their biological targets in the organism) $[1] ; 2$ ) development of drug resistance (during one year, approximately $50 \%$ of cancer patients gain resistance to applied chemotherapeutic drugs) [2]. How one can decrease negative side effects, namely cardio-, hepato-, nephro-, neuro-, and immunotoxicities observed at drug action in the organism? The elimination of such effects can be achieved via a decrease of acting drug concentration, or "masking" of toxic drug substance in order to avoid its non-addressed action in the treated organism.

The last two decades demonstrated a real burst of investigations dedicated to creation of novel nanomaterials for biology and medicine, as well as in development of the overlapping branches such as agriculture, ecology, cosmetic industry and others. If the early nanomaterials for the biomedical application possessed a limit- 
ed number of functional properties, nowadays, scientists created multifunctional nanomaterials that are, for example, capable of delivering the medicine, its bio-imaging for monitoring the addressed delivery and clearance, circumventing biological barriers in the organism, providing sensitivity to specific stimuli, and others. Thus, new terms have appeared such as "intellectual" or "smart" drugs, molecular nano-robots, etc. It is desirable that "smart" drugs and platforms used for their delivery possess organic structure being biocompatible and biodegradable. While various diagnostic remedies for monitoring pathological state may possess mineral basis, since they will not directly get into the organism, although there are exclusions from that rule.

\footnotetext{
Nanocapsulation of anticancer drugs in the developed polymeric carrier provides for the drug:

- Improved water solubility;

- Enhanced transportation to target cells;

- Preservation of rapid release from tissue;

- Enhanced crossing biological barriers;

- Increased drug stability;

- Effective engulfment of nanoparticles with encapsulated drug by target cells.
}

Main characteristics of nanoparticles for biology and medicine:

- Size (for clearance);

- Core (different nature);

- Coating (for biocompatibility);

- Labeling (for detection);

- Activation (for bio-functionalization);

- Bio-functionalization (for recognition by specific cells).

\section{Size of Particles for Biomedicine:}

\section{0-200 nanometers:}

- Cell bio-testing (ex. phagocytic activity);

- Drug delivery;

- Others.

1-2 micrometers:

- Cell binding and isolation.

\section{Core of Particles for Biomedicine:}

Polymeric:

- Reactive micelle forming oligoelectrolytes, derived metal complexes, telechelic, block and highly branched surfactants and their complexes with biopolymers

- Polystyrene, poly-acrylate, poly (styreneco-surfmer) including colored or luminescent label.
Mineral:

- Siliceous:

- Super-paramagnetic $\left(\mathrm{Fe}_{3} \mathrm{O}_{4}, \mathrm{Y}-\mathrm{Fe}_{2} \mathrm{O}_{3}, \mathrm{Ni}\right)$;

- $\mathrm{Au}, \mathrm{Ag}, \mathrm{Cu}, \mathrm{Pd}$;

- Fullerene;

- Others.

\section{Coating of nanoparticles:}

- Biocompatible synthetic shell based on vinyl pyrrolidone, vinyl alcohol, oxyethylated and fluorinated copolymers and their complexes with biopolymers;

- Bio-surfactants of microbial origin;

- Others.

\section{Chemical structure of the biodegradable} drug carrier:

- Poly (aspartic acid), poly (glutamic acid), poly (malic acid), poly (lactic acid), polysaccharides, others;

- Polymers can be considered degradable when they have following groups in their backbone chain: -O-, - $\mathrm{NH}-,-\mathrm{S}-$, and -S-S-

- In order to avoid immunogenicity, the number and kinds of amino acids should be kept low; maximum biological efficacy is possible at minimum immune response.

Biocompatibility of the developed nanoparticles can be achieved by:

- Size unimodality;

- Controlled amount and distribution of active groups;

- Opsonization of the particle surface by the biocompatible macromolecules.

\section{Activation of nanoparticle surface:}

- Incorporation of chemically active groups and branches such as hydroxyl, carboxyl, amino, aldehyde, epoxy, others.

\section{Bio-functionalization of nanoparticles is} done by:

- Lectins - recognition of carbohydrate moieties on cell surface and within different molecules

- Immunoglobulins - antibodies recognizing specific antigen structures on cell surface and macromolecules

Besides these proteins, other molecules can be used for "vectorization" of drug-functionalized nanoparticles. These are:

- Cytokines (ex. tumor necrosis factor alpha, interleukin 2, other) to which target cells have surface receptors; 
- Folate (tumor cells have overexpressed folate receptors);

- Laminin (tumor-specific form alpha 4/beta 1/gamma 1);

- Monoclonal antibody to transferrin receptor (serves for crossing endothelial system, namely blood-brain barrier (BBB) and blood-tumor barrier (BTB).

- Other.

Labeling of nanoparticles for their visualization (microscopic or imaging study)

- Labeling with optically dense elements (gold, silver, nickel, magnetite, magnemite, fragment of monomer dye, other);

- Fluorescent labeling (FITC, Texas red, others);

- Luminescent labeling (cations of rare earth elements $\mathrm{Ce}(\mathrm{III}), \mathrm{Nd}(\mathrm{III})$, pyrene, others).

Hub idea was proposed for maximum addressed delivery of drugs [3]:

- as a $1^{\text {st }}$ hub vector for crossing the endothelial barrier, hybrid proteins that contain specific cytokine and antibody against specific domains of endothelial cells can be used;

- as a $2^{\text {nd }}$ hub vector, antibodies to specific tissue antigens present on the way of drug delivery from blood vessels to tissue target are useful.

Different anti-cancer drugs (Doxorubicin, Cisplatin, Ruthenium-containing drug KP-1019, Lando- mycin A, novel 4-tiazolodininone derivatives) were conjugated with either poly(VEP-GMA)-graft-PEG additionally functionalized with phospholipid or conjugated with Fulleren C60. The drugs were applied in native and nanocarrier-immobilized forms for treatment of mammalian tumor cells of various tissue origin and with different mechanisms of resistance to anticancer drugs.

Immobilization of Doxorubicin and KP-1019 on a new polymeric-phospholipidic hybrid delivery system distinctly enhanced the accumulation and activity of these drugs in all tested tumor cell lines including several drug-resistant lines $[4,5]$. The resistance levels against Doxorubicin were reduced 6- to 22-fold (Figure 1). The new nanocarriers were shown to rapidly (within $10 \mathrm{~min}$ ) and effectively transport Doxorubicin into drug-resistant as well as drug-sensitive tumor cells. The treatment with new Doxorubicin-containing nanocarriers resulted in effective cell cycle arrest in G2/M phase and ROS-induced cell death. In both in vivo tumor models - murine NK/Ly lymphoma and murine L1210 leukemia - Doxorubicin delivery by the new nanoformulation resulted in $100 \%$ cured animals already at low concentrations $(0.1 \mathrm{mg} / \mathrm{kg})$, while the native Dox solely extended a survival time. Thus, polymeric nanocarriers functionalized with phospholipids and PEG enhance the efficacy and reduce the toxicity of Doxorubicin.

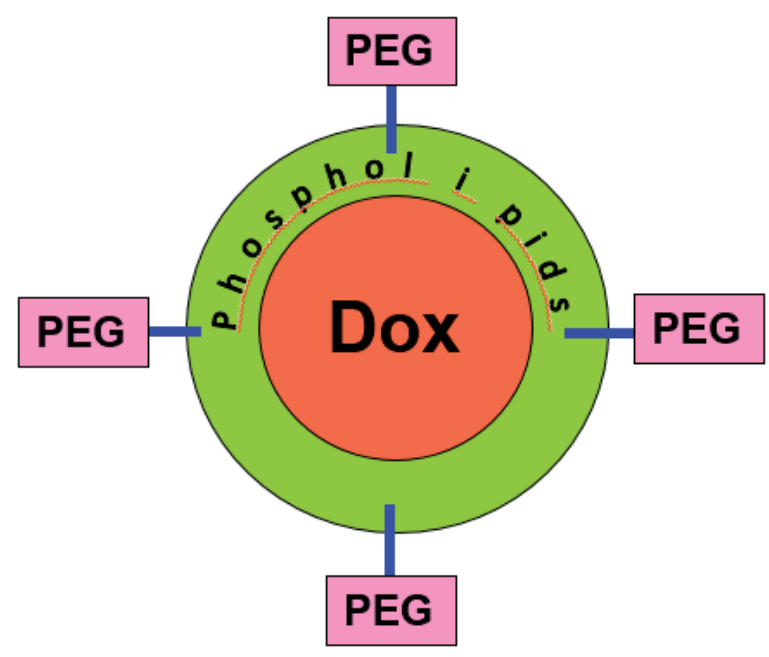

$100 \mathrm{~nm}$

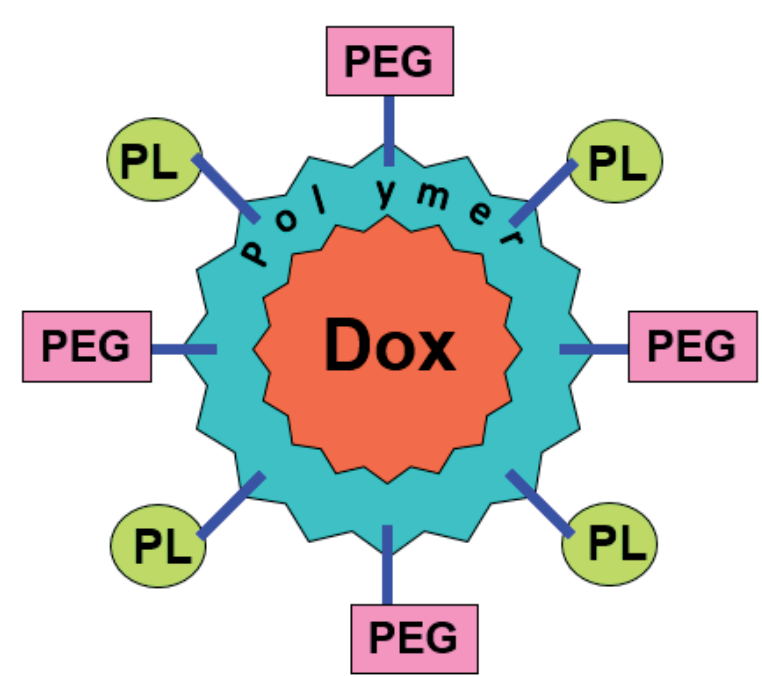

$\sim 100 \mathrm{~nm}$

Figure 1. A schematic structure of the FDA-approved liposomal nanoformulation Doxil (Johnson \& Johnson) compared to nanoscale polymeric platform with immobilized doxorubicin developed by Zaichenko at al. at Lviv National Technical University (Ukraine) [4,5]. Doxil (left), polymeric nanoplatform (right). PEG - polyethylenglycol, PL - phospholipid 
In another set of experiments, Doxorubicin or Cisplatin (CDDP) were immobilized on Fullerene C60 that enhanced an ability of these anticancer drugs to circumvent resistance of tumor cells to chemotherapy in vitro $[6,7]$. Cytotoxic activity of CDDP-C60 nano-complex towards different lines of drug-resistant tumor cells was 1.5-2.0 times higher than that of native CDDP. In parallel, an enhanced uptake of this drug and double induction of apoptosis in target tumor cells were observed. The anticancer effect of CDDP-C60 nano-complex was confirmed in tumor-bearing mice.

We also functionalized the developed polymeric nanocarriers with specific antibody or lectin in order to improve their cell targeting properties. We created functional nanoparticles targeting glycocalyx and used them for detection and isolation of specific mammalian cells [8]. Heterogeneity of murine lymphoma NK/Ly cells on peanut agglutinin (PNA) binding was revealed. Lymphoma cells were treated with native PNA, and bound PNA was detected by the anti-PNA antibodies labeled with colloidal gold and intensified by silver staining [8]. Such approach can be used for a search and isolation of drug resistant tumor cells.

Treatment effects of native and nanocapsulated anticancer drugs was also studied in vitro using several human and animal tumor cells and in vivo using murine NK/Ly lymphoma and L1210 leukemia as experimental models. In both in vitro and in vivo $[4,5]$ experiments, a decrease of acting concentrations of highly toxic anticancer drugs (ex. Doxorubicin) from $50 \%$ to 10 times (depending on specific target tumor cells and drugs) was found. Doxorubicin was encapsulated in the nanoscale polymeric carrier A-24-PEG$\mathrm{Ph}(0.1 \mathrm{mg} / \mathrm{kg}$ of mouse weight, 5-10 injections). Principal negative side effects of the action of toxic anticancer agents were shown to be significantly diminished by drug encapsulation and treatment of laboratory mice and rats. These effects are: hepatotoxicity, cardiotoxicity, nephrotoxicity. Stop of the neurotoxicity and immunosuppression is also

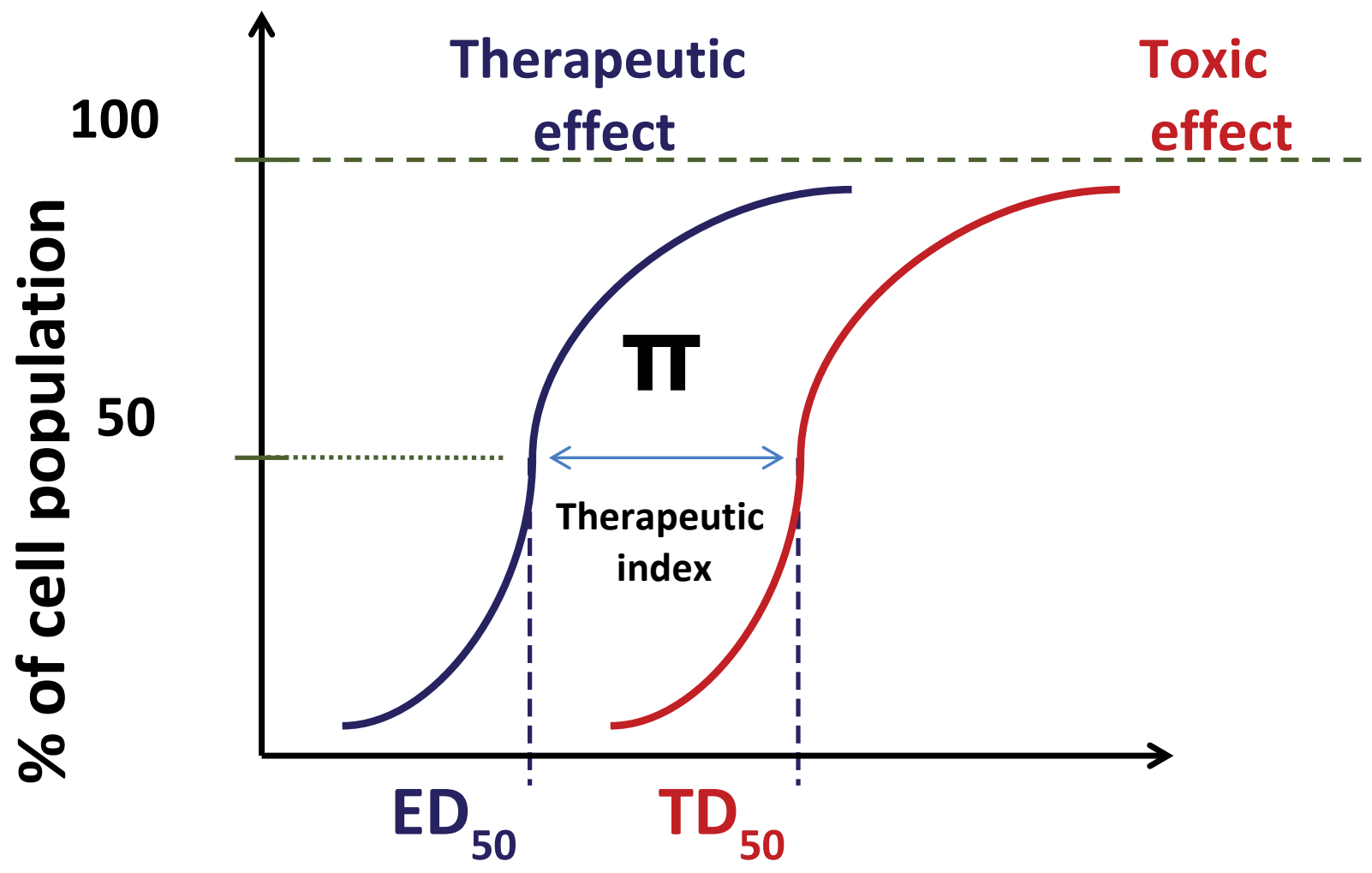

\section{Drug concentration}

Figure 2. Drug delivery by the nanocarrier should increase the Therapeutic Index 
suggested at using drug nanoformulation. In order to prove such effects, numerous biochemical indicators were measured in blood serum of animals treated with native and encapsulated anticancer drug $[9,10,11]$.

Thus, anticancer drug delivery by the developed polymeric nanocarrier increased significantly a therapeutic index that is an important indicator of the effectiveness and biosafety of drug action (Figure 2).

The main ideas presented in this paper were recently analyzed in the monograph that was edited by the author [12]. Some results noted in the paper were obtained in collaboration with investigators who are mentioned in the Acknowledgement below.

Acknowledgements: Zaichenko O., Mitina N., Ryabtseva A., Myahkota L., Hevus O., Senkiv Yu., Heffeter P., Berger W., Boiko N., Klyuchivska O., Finiuk N., Lootsik M., Panchuk R., Skorokhyd N., Lehka L., Prylutskyy Yu., Prylutska S., Evstigneev M., Potebnya G., Skivka L., Didenko G., Ritter U., Scharff P., Kobylinska L., Havrylyuk R., Kamynsky D., Lesyk R., Zimenkovsky B.

\section{References}

1. Ljubimova JY1 ${ }^{1}$, Fujita M, Ljubimov AV, Torchilin VP, Black KL, Holler E. Poly(malic acid) nanoconjugates containing various antibodies and oligonucleotides for multitargeting drug delivery. // Nanomedicine (Lond). 2008. Vol. 3, N2. - P.247-265.

2. Young RC. In: Drug resistance in cancer therapy. Kluwer, Dordrecht; 1989, P.1-26.

3. Senkiv Yu., Riabtseva A., Heffeter P., Boiko N., Kowol R., Jungwith U., Shlyakhtina Ye., Garasevych S., Mitina N., Berger W., Zaichenko A., Stoika R. Enhanced anticancer activity and circumvention of resistance mechanisms by novel polymeric/phospholipidic nanocarriers of doxorubicin // J. Biomedical Nanotechnology. - 2014. - Vol. 10, N. 7. - P. 1369-1381.

4. Heffeter P., Riabtseva A., Senkiv Yu., Kowol R.C., Koerner W., Jungwith U., Mitina N., Keppler B.K., Konstantinova T., Yanchuk I., Stoika R., Zaichenko A., Berger W. Nanoformulation improves activity of the (pre)clinival anticancer ruthenium complex KP1019 // Journal of Biomedical Nanotechnology. 2014. - Vol. 10 N 5. - P. 877-884.

5. Chu LH, Chen BS. Construction of a cancer-perturbed protein-protein interaction network for discovery of apoptosis drug targets // BMC Syst Biol. 2008 Jun 30;2:56. doi: 10.1186/1752-0509-2-56.

6. Panchuk R.R., Prylutska S.V., Chumak V.V., Skorokhyd N.R., Lehka L.V., Evstigneev M.P., Prylutskyy Yu.I., Berger W., Heffeter P., Scharff P., Ritter U., Stoika R.S. Application of C60 Fullerene-Doxorubicin Complex for Tumor Cell Treatment In Vitro and In Vivo // J. Biomed. Nanotechnol. - 2015. - Vol. 11, N.7. - P. 1139-1152.

7. Svitlana Prylutska, Rostyslav Panchuk, Grzegorz Gołuński, Larysa Skivka, Yuriy Prylutskyy, Vasyl Hurmach, Nadya Skorohyd, Agnieszka Borowik, Anna Woziwodzka, Jacek Piosik, Olena Kyzyma, Vasil Garamus, Leonid Bulavin, Maxim Evstigneev, Anatoly Buchelnikov, Rostyslav Stoika, Walter Berger, Uwe Ritter, and Peter Scharff. C60 fullerene enhances cisplatin anticancer activity and overcomes tumor cell drug resistance. Nano Research (2016) DOI 10.1007/s12274-016-1324-2

8. Lootsik M.D, Boiko N.M., Mitina N.Ye., Klyuchivska O.Yu., Lootsik M.M., Konstantinova T.Ye., Zaichenko O.S., Stoika R.S. Fractionation of cellular populations by superparamagnetic particles with defined functional properties of their surface. // Biotechnologia Acta. - 2014. - Vol. 7, N 1. P. 80-86.

9. Kobylinska LI, Havrylyuk DY, Ryabtseva AO, Mitina NE, Zaichenko OS, Lesyk RB, Zimenkovsky BS, Stoika RS. Biochemical indicators of hepatotoxicity in blood serum of rats under the effect of novel 4-thiazolidinone derivatives and doxorubicin and their complexes with polyethyleneglycol-containing nanoscale polymeric carrier. // Ukr Biochem J. - 2015. - V. 87, N2. - P. 122-132.

10. Kobylyns'ka LI, Havryliuk DIa, Riabtseva AO, Mitina NIe, Zaichenko OS, Zimenkovskyı̆ BS, Stoľka RS. Study of rat blood serum biochemical indicators of cardiotoxic action of novel antitumor 4-thiazolidinone derivatives and doxorubicin in complexes with polyethylene glycol-containing polymeric carrier in the rat blood serum. // Ukr Biochem J. 2014 - V.86 N6, 84-95.

11. Kobylinska L.I. Havrylyuk D.Ya., Mitina N.E., Zaichenko A.S., Lesyk R.B., Zimenkovsky B.S., Stoika R.S.Biochemical indicators of nephrotoxicity in blood serum of rats treated with novel 4-thiazolidinone derivatives or their complexes with polyethyleneglycol-containing nanoscale polymeric carrier. // Ukr. Biochem. J. 2015. - Vol. 87, N2. - P. 122-132.

12. Multifunctional nanomaterials for biology and medicine: molecular design, synthesis, and application (Chief Editor - Stoika R.S.), Naukova Dumka, Kyiv, 2017, 364 p.

Стаття надійшла 1.06.2017

Після допрацювання 19.06.2017

Прийнята до друку 26.06.2017 